and in some cases without, examination. Professor Struthers has already pointed out that a similar allegation referring to the University of Aberdeen is absolutely false. It is not less so in reference to the Corporations. The examinations for the licence of the three Corporations are managed by a committee of representatives who are not examiners. The Board of Examiners is drawn from the schools of Edinburgh and Glasgow, is composed of the men who are most distinguished in the various departments, and is at the same time the largest board of examiners in the three kingdoms. There has thus been secured, not only a high standard, which is common enough, but also a discouragement of special cramming, and a justice and uniformity which are not easily attained. If the value of the examinations be estimated by the average number of rejections, it will be seen by the published returns that they bear favourble comparison with all others. At the last sederunt, the rejections were over 60 per cent., larger than usual by 5 or 6 per cent. It may frankly be admitted that none of these rejections arise from the fact that statements such as those referred to induce a certain number of unprepared men from other schools to make their appearance for examination here. These men, being relegated to their studies occasionally, continue their studies in the Scottish schools, and subsequently pass. In regard to higher titles, the Fellowship of the Royal College of Surgeons of Edinburgh is granted very rarely, perhaps once in one or two years, on the recommendation of the Council and by ballot of the College "to men who have highly distinguished themselves by original investigations, and possess registrable surgical qualifications of a sufficiently ligh order." (See Laws, p. 20.)

This is the case with most similar titles. But with this exception, the Fellowship is granted only after examination, the stringency of which may be judged by the fact that at the last examinations out of twenty-two candidates twelve were rejected. The recent action of certain provincial hospital boards has plainly been based on a narrow spirit of trades unionism, and not upon a just estimate of the value of the higher titles granted by the Scottish Colleges.

I am, Sirs, your obedient servant,

JOHN DUNCAN.

Edinburgh, July 25th, $1890 . \quad$ President R.C.S.Ed.

\section{NURSES AT ASYLUMS.}

\section{To the Editors of THE LANCET.}

SIRS, - In the last issue of THE LANCET I read with much interest your commissioner's report on the duties \&c. of hospital nurses. Your reporter therein remarks: "But what strikes me as being the most urgent demand is for a shortening of the hours of unrelieved work. The twelve hours' system is a cruel strain on a woman's strength and nerve." Now, if the duties of a nurse in a quiet, orderly assembly of sane patients be so trying, what must it be to spend twelve or more hours amidst excited, violent, suicidal, or dirty lunatics? My object in writing to you is to express my hope that after you have dealt with the case of hospital nurses you will appoint a commission to investigate the hours of duty and amount of pay with respect to asylnm nurses. I feel it will be found practically impossible to do much towards lessening the daily hours of duty, but a comparatively small proportional addition to an asylum staff would enable each nurse to have one day's leave each week, in addition to the leave already allowed; thus a good reduction in the weekly hours of duty would be effected. A still more important matter is that of pay and pension. At present, if a nurse saved the whole of her wages for twenty-five years the amount would be inadequate to bny an annuity, or produce interest that would suffice to feed and clothe her. Hence, in my opinion, every asylum nurse or atten. dant should be entitled to a minimum pension of $£ 26$ a year after twenty or twenty-five years' service in wards containing dangerous and harassing patients. If the pension were secure wages would not require to ke raised. THE LANCET has been potent in bringing about important reforms. If it could effect some such changes as I have indicated it would hestow an inestimable boon upon hundreds of most deserv. ing persons.

I remain, Sirs, your obedient servant,

\section{"M. PASTEUR AND HYDROPHOBIA."}

IN connexion with the letter under the above heading, which appeared in our last week's issue, the following correspondence has been sent to us for publication :Horton House, Halifax, July 18th, 1890. DEAR SIR,-In reply to your letter of July $17 \mathrm{th}$, I have the following bservations to make :-

1. M. Pasteur, in a popular magnzine, the New Review", appealed " to a public imperfectly educated in medical and scientific matters" in support of his system.

2 . I have demonstrated, with the precision of a mathematical problem the fallacies of the method, in another popular review, and only the most blinded partisan can refuse to accent iny conclusions. I was not the first to appeal to a general public "necessarly ignorant on such matters." I think you rather under-estimate the intelligence of the public to which you and the Pasteurians did not hesitate to appeal a the Mansion House meeting. 3. You have, it is true, contradicted my statements in the British
Medical Journal, and you have ostentatiously labelled your own opinions as facts. I decline to have ostentatiously labelled your own opmion questions at issue. I prefer, even to your opinions, those of Professor Puestions at issue. I prefer, even to your opinions, those of Professor
Peter (Paris), Professor Billroth (Vienna), Professor Abreu (Portugal), Peter (Paris), Professor Billroth (Vienna), Professor Abreu (Portugal),
Professurs De Renzi and Amoroso (Naples), Professor von Frisch Professurs De Renzi and Amoroso (Naples), Professor von Finsch
(Vienna), Dr. B. W. Richardson (London), Vincent Richards (Calcutta), (Vienna), Dr. B. W. Richardson (London), Vincent Richards (Calcutta),
Dulles (Philadelphia), Herman Biggs (New York), \&c. If I err, I err in very good company.

4. I quoted your words under a special heading. They are absolutely 4. I quoted your words under a special heading. They are absolutely
correct. There is no suppression on the point at issue, and there was no necessity to bring in another subject

5. If you will point out any individual misstatements in my article in the Contemporary in connexion with your name, $Y$ shall be obliged, and can then deal with them.

(i. You can, by manipulation of figures, prove to your own satisfaction that $M$. Pasteur has saved 900 or $\approx 000$ lives, or reduced the mortality from 15 to $1 \cdot 6$ per cent. You might as well have said that he had reduced it from 65 or 93 to 1 per cent. I have no doubt you were satisfied with your figures as given to the Epidemiological Society. I was present, and was not satisfed except on one point-viz, to find that you agreed to an old opinion of mine expressed in the Practitioner of 1881 , and contained in a Dog Act (which has since been copied), that rigorous police
measures should be sufficient to keep down rabies and the accompanying mortality from hydrophobia.

7. I cannot repeat "misstatements," as I have not made any; but I am quite prepared to substantiate iny opinions in medical journals or at scientific societies should occasion arise.

The problem now resolves itself, apart from all "enebriation" of figures, into a simple one: "Has M. Pasteur reduced the mortality from hydrophobia in a given district-the department of the Seinewhere he has been operating under the most favourable conditions?" The answer is given by the death-rate, published by Dr. DujardinBeaumetz. If you care to defend this at the Congress at Berlin, I shall reply to you in the negative. I desire to speak out plainly, and I now reply to you in the negative. I desire to speak out plainly, and I now
take the trouble to tell you-I hope for the last time-that any little take the trouble to tell you-I hope for the last time-that any little.
efforts I can render to humanity to rid it of this incubus in the shape of efforts $I$ can render to humanity to rid it of this incubus in the shape of
Pasteurism shall be readily and gladly given, for I am convinced that so far from lessening the sum of human misery caused by hydrophobia, so far from lessening the sum of human misery caused by hydrophobia,
Pasteur has increased it. Wherever a Pasteur Institute has sprung up Pasteur has increased it. Wherever a Pasteur Institute has sprung up dog-bitten have increased; the fear and misery caused by dog bites dog-bitten have increased; the fear and misery caused by dog bites have been intensitied; whilst I need not say that the brute creation has
fared even worse. I commend to your attention the opinion of thie fared even worse. I commend to your attention the opinion of thit editor of the New York Medical hecord on the establishment recently
opened at New York. I hope my efforts in the Contemporary may do some good to counteract the propagandism in favour of the Pasteurian system initiated in the lay press by Pasteur himself and his adherents. To victor

$$
\begin{aligned}
& \text { I remain yours very faithfully, } \\
& \text { THOMAS M. DOLAN. }
\end{aligned}
$$

80, Park-street, Grosvenor-square, W., July 96 th, 1890. SIR,-By way of answering the letter in which I exposed your misrepresentations of my statements you make a fresh assertion of equally erroneous character-viz , that $\mathbf{I}$ ostentatiously "label my own opinions as facts." Since your memory of the facts, not opinions, given in the paper, at the reading of which you admit you were present, has apparently failed you, I advise you to honestly refer to it ; but after no further part in this correspondence. - Faithfully yours,

T. M. Dolan, Esq. VICTOR HORSLEY

I shall feel obliged by your sending this letter to your exchanges, or by sending me their names for that purpose.

\section{MANCHESTER.}

(From our own Correspondent.).

\section{River Follution.}

AN important step has lately been taken here, which may ulcimately lead to a considerable improvement in the filthy condition of the rivers running through the city, in the shape of a conference of the representatives of the Lancashire and Cheshire County Conncils, together with those from many of the large boroughs of the two counties, with the object of taking combined action in preventing the pollution of the rivers Irwell, Mersey, and Medlock with their numerous tributaries. As the watershed thus involved reaches to some sixty or seventy miles of river, the work is one of considerable magnitude. It is, nevertheless, especially to 